Jpn. J. Ornithol. 49: 59-61, 2000

\title{
Sexual Dimorphism of the Red-billed Leiothrix Leiothrix lutea
}

\author{
Katsura K. Kawano, Hitoha E. Amano and Kazuhiro EguchI
}

The Red-billed Leiothrix Leiothrix lutea is distributed from the Himalayas south and east to Myanmar and southern China (Long 1981). In Japan it has become naturalised after escaping from captivity and also because individuals imported for use in the cosmetic industry have been released. Major naturalised populations inhabit Mt. Rokko in Hyogo Prefecture, Mt. Tsukuba in Ibaraki Prefecture and mountainous areas of Kyushu. Numbers have been increasing since the early 1980s (Eguchi \& Masuda 1994; Tojo 1994).

There is little data available on the behavior and life history of the Red-billed Leiothrix in the wild in Japan due to the difficulty of observing them in their favoured densely vegetated habitats. Determining the sex of birds in the field is another problem. It has been shown that even the presence of a brood patch is not a reliable indicator of sex because both males and females incubate (Ralph et al. 1998). One method of sexing this species is by the difference in the shape of the cloacal region but this is only possible during the breeding season and detection requires some skill.

The Red-billed Leiothrix has a bright red bill, red and yellow patches on dark greyish-green wings and an orange throat. Bright plumage, in general, is used to attract mates (Moller 1994) and among passerines males are usually brighter than females. Even in species with little colour sexual dimorphism, colour patches are associated with mate choice (Norris 1990). In the Red-billed Leiothrix, the bright bill and colour patches are common to both sexes, however, individual differences in the brightness and size of colour patches were detected during our preliminary observations.

The aims of this study were: 1) to detect morphological sexual differences recognisable in the field, and 2) based on variations of individual traits, to examine which characteristics are related to sexual selection.

The study was conducted in the Ebino Plateau region of Miyazaki and Kagoshima Prefectures $\left(31^{\circ} 81^{\prime} \mathrm{N}, 130^{\circ} 65^{\prime} \mathrm{W}\right)$. Red-billed Leiothrix were captured with mist nets between April and August 1997 and 1998. Each bird was banded with two or three coloured plastic rings, and they were also measured body size(as follows (1)-(5), (12)) and the size of the colour patches ((6)(11)) was noted and blood sampleswere collected to aid molecular sexing. Each individual was measured according to Svensson (1992) with the exception of tail length, which was measured by placing the zero stop of a ruler onto the oil gland and reading the measurement at the tip of the tail.

We measured 12 characteristics of each bird: 1) maximum wing length, 2) tail length, 3) tarsus length, 4) total culmen, 5) depth of bill, 6) length of supercilium (measured from nostril to ear coverts), 7) length of throat patch (measured by extending the head very gently, and measuring the length of the yellowish patch from chin to breast, 8) width of throat patch (measured by gently gripping and stretching the head and measuring the maximum extension of the yellowish breast patch), 9) length of red wing patch (maximum measurement of the length of the red patch between the first and third primaries, 10) length of the yellow wing patch (maximum measurement of the length of the yellow patch between the first and third secondaries, 11) maximum width of the white tips to upper tail coverts, and 12) body weight.

Wing and tail measurements were made with a ruler to the nearest $0.5 \mathrm{~mm}$, and other measurements were made with digital callipers to the nearest $0.01 \mathrm{~mm}$. Body weight was determined to the nearest $0.1 \mathrm{~g}$ with a digital scale.

A small amount of blood (50-100 $\mu 1)$ was collected from each bird for molecular sexing. DNA was extracted using phenol-chloroform or an extracting kit (Gentle-kun ${ }^{\mathrm{TM}}$ (Takara Co.)). For standard sexing, we followed Ellegren's (1996) molecular sexing method, which is applicable to all avian taxa other than ratites (Struthioniformes) (Ellegren 1996).

Primers PCR 2945F and 3224R were used to amplify 630 base pair (bp) fragments in both sexes, and $2945 \mathrm{~F}$ and cfR were used to amplify $210 \mathrm{bp}$ that were sex-linked fragments. Amplified products wer checked by electrophoresis in 1.6\% agalose gel. Molecular sexing was applied to 
Table 1. Comparison of mean, standard deviation and coefficients of variation of measurements. The $p$-value was obtained by the $t$-test which compares the mean between males $(\mathrm{n}=$ 80 ) and females $(\mathrm{n}=33)$.

\begin{tabular}{|c|c|c|c|c|c|c|c|}
\hline & \multicolumn{3}{|c|}{ male } & \multicolumn{3}{|c|}{ female } & \multirow[b]{2}{*}{$P$} \\
\hline & mean & $\mathrm{SD}$ & $\mathrm{CV}$ & mean & $\mathrm{SD}$ & $\mathrm{CV}$ & \\
\hline Wing lengh & 68.1 & 2.43 & 0.04 & 65.9 & 2.03 & 0.03 & $\left\langle 0.001^{*}\right.$ \\
\hline Tarsus length & 24.73 & 0.82 & 0.03 & 24.36 & 0.70 & 0.03 & 0.256 \\
\hline Tail length & 59.3 & 2.02 & 0.03 & 57.7 & 1.92 & 0.03 & $0.001^{*}$ \\
\hline Total culmen & 15.85 & 0.79 & 0.05 & 15.46 & 0.39 & 0.03 & $0.0084^{*}$ \\
\hline Depth of bill & 4.64 & 0.21 & 0.04 & 4.48 & 0.18 & 0.04 & $0.0002^{*}$ \\
\hline Weight & 22.1 & 1.21 & 0.05 & 21.7 & 1.12 & 0.05 & 0.1433 \\
\hline Length of supercilium & 16.66 & 1.51 & 0.09 & 15.75 & 1.23 & 0.08 & $0.0034^{*}$ \\
\hline Throat-patch length & 43.20 & 4.67 & 0.11 & 41.30 & 4.75 & 0.12 & 0.0521 \\
\hline Throat-patch width & 26.21 & 2.70 & 0.10 & 26.14 & 3.70 & 0.14 & 0.9069 \\
\hline Yellow wing-patch & 7.85 & 1.57 & 0.20 & 6.40 & 2.10 & 0.33 & $0.0001^{*}$ \\
\hline Red wing-patch & 15.67 & 1.86 & 0.12 & 12.82 & 2.06 & 0.16 & $\left\langle 0.0001^{*}\right.$ \\
\hline Tail's white tip & 1.17 & 0.44 & 0.38 & 0.60 & 0.33 & 0.54 & $\left\langle 0.0001^{*}\right.$ \\
\hline
\end{tabular}

Weight:g, the others:mm, ${ }^{*}$ :appropriate critical value for the twelve individual traits after Sequential Bonferroni test $(P<0.05)$.

twelve individuals which had previously been sexed based on their breeding behaviour (six males and six females), and confirmed that sexing had been correct.

For the analysis of dimorphism, we used the Canonical discriminant function (Manly 1994). Using "Mathematica 3.0" software we estimated the eigenvector and eigenvalue of the function, and used "Statview 4.5J" for parametric analysis.

We captured 78 individual Leiothrix in 1997 and 110 in 1998. Eighty-eight males and 33 females were sexed using the molecular sexing method and we have used these results in our analysis. Males were found to be significantly larger bodied ((1), (2), (4), (5)) and to have larger colour patches ((6), (9)-(11)) than females (see Table 1). We obtained three variables to maximise the ratio of within group variance/between group variance using Canonical discriminant analysis, these were wing length (WL), red wing patch (RP) and white tips of upper tail coverts (WT). These variables were not correlated mutually (WL, RP: $r_{\text {male }}=0.100, r_{\text {female }}=$ $0.239, \mathrm{WL}, \mathrm{WT}: \mathrm{r}_{\text {male }}=0.228, \mathrm{r}_{\text {female }}=-0.035, \mathrm{RP}$, WT: $r_{\text {male }}=0.152, r_{\text {female }}=0.209$; Bartlett sphericity tests: female: $\chi^{2}=3.680$, df $=5, P=0.593$, and male: $\chi^{2}=6.482$, df $\left.=5, P=0.212\right)$, and satisfied equality of population covariation $\left(\chi^{2}=18.55\right.$, df $=6, P<0.005)$.

The Canonical discriminant function is given as following equation: $Z=0.091 \mathrm{WL}+0.236 \mathrm{RP}+0.967$ WT -10.606 Eigenvalue was $0.806\left(\Phi^{2}=31.9202\right.$, $P<0.005)$; significantly different between sexes.
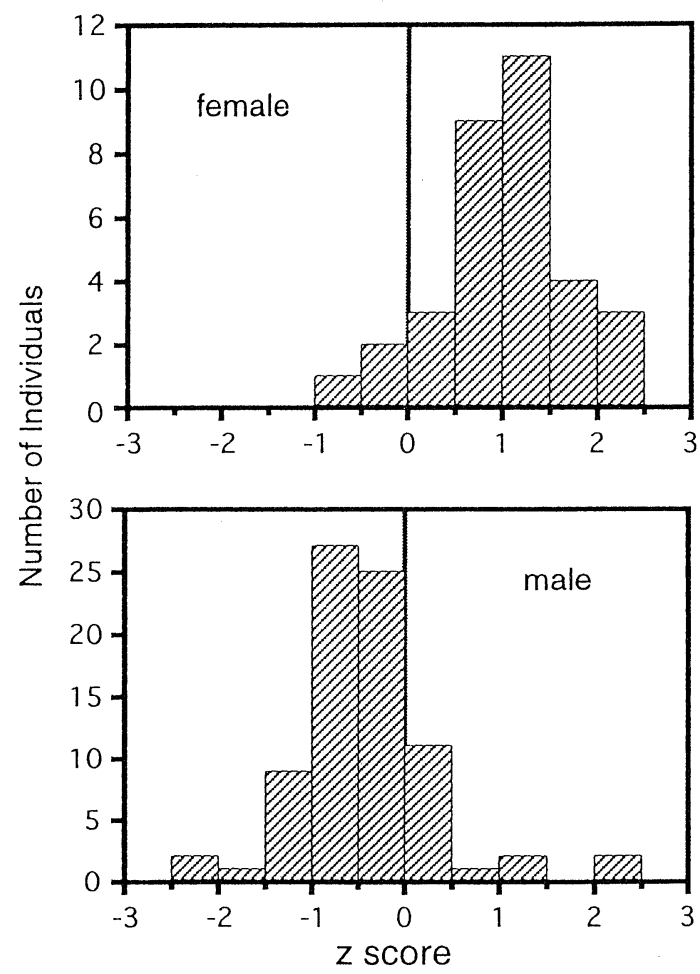

Fig. 1. Distribution of the discriminant scores for 33 female and 80 male birds. The eigenvalue was $0.806\left(\Phi^{2}=31.920, P\right.$ $<0.005)$, and, thus, $Z$ differed significantly between sexes. 
The error rate of discrimination was $18.8 \%$ ( $=$ $15 / 80)$ for males, $9.1 \%(=3 / 33)$ for females, and $15.9 \%(=18 / 113)$ for both sexes combined (see Fig. 1.). Due to imperfect age determination, some immature individuals may have been included in samples; there was a higher error rate of discrimination among males.

Because there was no significant correlation between wing length and colour wing patch size within each sex, differences in coloured wing patches were less influenced by those of wing length. Additionally, measurements of coloured wing patches showed larger coefficients of variation than those of ordinary traits such as wing length (Table1) and contributed to discriminate sex. It is known that ordinary characters, such as wing length, have small coefficients of variation (Grant \& Price 1981; Alatalo et al. 1988), while secondary sexual characters have large coefficients of variation over 0.1 (Alatalo 1984; review in Møller \& Pomiankowski 1993). Ordinary morphological traits are generally subject to strong stabilizing selection; in contrast secondary sexual traits are subject to both stabilizing selection and strong directional sexual selection (Møller 1994). Moreover, under directional selection for larger coloured wing patches in males, CVs of secondary characters of males will be smaller than those of females.

Our results suggest that the brightly coloured wing patches of the Red -billed Leiothrix are secondary sexual traits. There is also the possibility that females prefer larger wing patches on males, and that males with the largest and brightest wing patches are preferentially selected.

Furthermore, among birds living in dark habitats (Phylloscopus species and Regulus regulus), individual inter- and intra-specific communication by means of plumage patterns has been suggested (Marchetti 1993). Because the Red-billed Leiothrix also prefers dark and densely vegetated habitats, coloured wing patches might be used for signalling during courtship displays.

We would like to thank Drs. Tetsukazu Yahara and Eiiti Kasuya for their encouragement and advice. We are also grateful to Dr. Akihiro Konuma for his technical advice for the molecular sexing and finally, we would like to thank members of the laboratory of Ecology, Department of Biology, Faculty of Science, Kyushu University, for their encouragement.

LITERATURE CITED : Alatalo, R. V., Holung, J. \& Lundberg, A., 1988. Sexual selection models and patterns of variation in tail ornaments in birds. Biol. J. Linn. Soc. 34: 363-374. @Ellegren, H.
\& Sheldon, B. C., 1997. New tools for sex identification and the study of sex allocation in birds. Trends in Ecol. Evol. 12: 255-259. @Eguchi, K. \& Masuda, T., 1994. A report on the habitats of Peking Robin Leiothrix lutea in Kyushu. Jpn. J. Ornithol. 43: 91-100. (in Japanese with English summary). Grant, P. R. \& Price, T. D., 1981. Population variation in continuously varying traits as an ecological genetics problem. Am. zool. 21: 795-811. @Long, J. L., 1981. Introduced Birds of the World. Reed, Wellington. Manly, B. F. J., 1994. Multivariate Statistical Methods, second edition. Chapman \& Hall, London. Marchetti, K., 1993. Dark habitats and bright birds illustrate the role of the environment in species divergence. Nature 362 : 149-152. OMøller, A. P., 1994. Sexual Selection and the Barn Swallow. Oxford University Press. New York.

\section{ソウシチョウにおける性的二型}

ソウシチョウ Leiothrix lutea において12の形質を計 測し、DNA性判定技術を用いて、（1）雌雄の形態的性 差を明らかにし、(2)これらの形態的性差への性淘汰の 関与について考察した。ソウシチョウのオスではメス よりも体サイズが大きく、翼の赤・黄色の斑、上尾筒 先端の白带も有意に大きかった。これらの形態的形質 をもとに正準判別関数 $Z=0.091 \times$ (最大翼長 $)+0.236$ $\times($ 翼の赤い斑の長さ $)+0.967 \times($ 上尾筒先端の白帯幅 $)-$ 10.606によって高い率で形態的形質から雌雄を判別す ることができた。また、形態的性差に寄与していた翼 の色斑は翼長と独立で変動係数が非常に大きいことか ら、性淘汰に関与していることが示唆され、色斑の変 動係数はオスよりあメスで大きかったことから、方向 性淘汰にさらされている可能性があると思われる。 一河野功ら・天野一葉・江口和洋

Authors' address: (Kawano \& Eguchi) Department of Biology, Faculty of Science, Kyushu University, Hakozaki, Fukuoka, 812-8581, Japan. 九州大学大学 院理学部生物科学専攻生態科学研究室. T812-8581 福岡市東区箱崎6-10-1, (Amano) Graduate School of Social and Cultural Studies, Ropponmatsu, Fukuoka, 810-8560, Japan. 九州大学大学院比較文化社会研究科 （自然史） $\mathbf{7} 810-8560$ 福岡市中央区六本松

(Received 27 December 1999; Accepted 1 May 2000) 